\title{
CNS Hypoxia Is More Pronounced in Murine Cerebral than Noncerebral Malaria and Is Reversed by Erythropoietin
}

\author{
Casper Hempel, ${ }^{* \dagger}$ Valery Combes, ${ }^{\dagger}$ \\ Nicholas Henry Hunt, ${ }^{\ddagger}$ \\ Jørgen Anders Lindholm Kurtzhals, ${ }^{*}$ and \\ Georges Emile Raymond Grau ${ }^{\dagger}$
}

\begin{abstract}
From the Centre for Medical Parasitology," Department of Clinical Microbiology, Copenhagen University Hospital (Rigshospitalet), and the Department of International Health, Immunology and Microbiology, University of Copenhagen, Copenhagen, Denmark; the Vascular Immunology Unit, ${ }^{\dagger}$ Discipline of Pathology, and the Molecular Immunopathology Unit, ${ }^{\ddagger}$ Bosch Institute and School of Medical Sciences, Sydney Medical School, University of Sydney, New South Wales, Australia
\end{abstract}

Cerebral malaria (CM) is associated with high mortality and risk of sequelae, and development of adjunct therapies is hampered by limited knowledge of its pathogenesis. To assess the role of cerebral hypoxia, we used two experimental models of CM, Plasmodium berghei ANKA in CBA and C57BL/6 mice, and two models of malaria without neurologic signs, $P$. berghei $\mathrm{K173}$ in CBA mice and $P$. berghei ANKA in BALB/c mice. Hypoxia was demonstrated in brain sections using intravenous pimonidazole and staining with hypoxia-inducible factor-1 $\alpha$-specific antibody. Cytopathic hypoxia was studied using poly (ADP-ribose) polymerase-1 (PARP-1) gene knockout mice. The effect of erythropoietin, an oxygen-sensitive cytokine that mediates protection against $\mathrm{CM}$, on cerebral hypoxia was studied in $\mathrm{C} 57 \mathrm{BL} / 6$ mice. Numerous hypoxic foci of neurons and glial cells were observed in mice with CM. Substantially fewer and smaller foci were observed in mice without $\mathrm{CM}$, and hypoxia seemed to be confined to neuronal cell somas. PARP-1-deficient mice were not protected against $\mathrm{CM}$, which argues against a role for cytopathic hypoxia. Erythropoietin therapy reversed the development of $\mathrm{CM}$ and substantially reduced the degree of neural hypoxia. These findings demonstrate cerebral hypoxia in malaria, strongly associated with cerebral dysfunction and a possible target for adjunctive therapy. (Am J Pathol 2011, 179:1939-1950; DOI: 10.1016/j.ajpath.2011.06.027)
Cerebral malaria (CM) is the most serious complication of Plasmodium falciparum infection. Impaired cerebral microcirculation owing to sequestering of parasitized erythrocytes, platelets, and leukocytes is believed to be a major contributor to pathogenesis. ${ }^{1-3}$ The resulting tissue damage may be, at least in part, a consequence of oxygen deprivation. ${ }^{4,5}$ Although there are considerable indications of the importance of hypoxia in the pathogenesis of $\mathrm{CM}^{6-8}$ further direct evidence is needed to clarify the relative importance of the various consequences of impaired microcirculation. Thus, it is essential to quantify the extent of hypoxia in $\mathrm{CM}$ in situ and to study the association between hypoxia and clinical outcome.

Oxygen is a prerequisite for normal mammalian cellular function, and quick adaptations of the transcriptome occur to reduce hypoxia-associated tissue damage. During hypoxia, the transcription factor hypoxia-inducible factor (HIF) $-1 \alpha$ is rapidly up-regulated, ${ }^{9,10}$ and failure to adapt to hypoxia leads to irreversible cellular and tissue disease. ${ }^{11}$ Moreover, oxygen is an important oxidant that maintains cellular homeostasis and provides the basis for aerobic metabolism. ${ }^{12}$ Even in the presence of oxygen, cellular respiration can be severely impaired because of lack of reductants. This finding is important in conditions such as sepsis, and a key enzyme in this process is poly (ADP-ribose) polymerase-1 (PARP-1), which depletes cellular stores of NAD and NADH, thereby disrupting the intracellular redox state. ${ }^{12}$ This so-called cytopathic hypoxia ${ }^{10,12,13}$ could have a role in severe malaria, which in some respects resembles sepsis. ${ }^{14}$

Supported by Aase og Einar Danielsen Fonden, Fonden til Lægevidenskabens Fremme, and the Australian National Health and Medical Research Council (NHMRC project grants 571014 and 512469). C.H. was funded by a grant from the Danish Council for Independent ResearchMedical Sciences (FSS; grant 2112-04-0015)

Accepted for publication June 28, 2011.

C.H. and V.C. contributed equally to this work.

Supplemental material for this article can be found on http://ajp. amjpathol.org or at doi: 10.1016/j.ajpath.2011.06.027.

Address reprint requests to Casper Hempel, Ph.D., KMA7602, Copenhagen University Hospital, Blegdamsvej 9, Copenhagen Ø 2100, Denmark. E-mail: casperhempel@gmail.com. 
There is substantial indirect evidence of cerebral hypoperfusion in $\mathrm{CM}$ in humans. Noninvasive imaging of retinal and rectal vessels in patients with CM clearly demonstrates hypoperfusion and occlusion of the microcirculation, ${ }^{15-21}$ which is reflected by a clear association with a poor clinical outcome. ${ }^{16,21-23}$

Murine models of $\mathrm{CM}$ have important similarities to $\mathrm{CM}$ in humans ${ }^{2,24}$ including increased intracranial pressure and a significant decrease in cerebral blood flow, which progressively deteriorates as the clinical condition becomes aggravated. ${ }^{25}$ The decrease in cerebral blood flow leads to an altered metabolic profile in the cerebral tissue, which suggests cerebral ischemia. ${ }^{26,27}$ Recently, in the Plasmodium berghei ANKA (PbA) mouse model of $\mathrm{CM}$, intravital microscopy demonstrated cells plugging cerebral vessels, leading to markedly decreased cerebral blood flow. ${ }^{28}$ Vasospasms are detected in both human and murine CM, which may contribute to cerebral hypoperfusion along with cell-mediated congestion. ${ }^{28-32}$ Improving hypoperfusion and ischemia by increasing the oxygenation of the cerebral tissue might improve the outcome of severe malaria. ${ }^{5,15}$ In murine CM, hyperbaric oxygen therapy leads to marked clinical improvement, ${ }^{33}$ and injection of the hypoxia-responsive hormone erythropoietin (EPO) decreases cerebral disease and improves survival. ${ }^{34,35}$

The present study provided a direct measurement of the extent of hypoxia in murine $\mathrm{CM}$ and investigated the extent to which hypoxia may be related to the clinical course of the infection. Detecting hypoxic foci in affected tissue is possible through retro-orbital injection of pimonidazole $\mathrm{HCl}$ in vivo. Pimonidazole acts as a probe specific for hypoxia because at $\mathrm{pO}_{2}<10 \mathrm{~mm} \mathrm{Hg}$, it is reduced to a reactive intermediate that binds covalently to molecules containing a-SH group, including proteins, and can be detected by a specific monoclonal antibody. ${ }^{36,37}$ Thus, the hypothesis that cerebral hypoperfusion in experimental $\mathrm{CM}$ is associated with hypoxia can be directly tested. We assessed the extent of hypoxia and subsequent $\mathrm{HIF}-1 \alpha$ response in $\mathrm{CM}$ and non-CM using several murine models and neuroprotective treatment. Furthermore, the possible role of cytopathic hypoxia was tested as a driving force for $\mathrm{CM}$ progression in PARP-1 gene knockout (PARP-1 ${ }^{-1-}$ ) mice.

\section{Materials and Methods}

\section{Mice, Parasites, and Infection}

Female, 7-week-old, CBA mice (Animal Resources Centre, Canning Vale, Western Australia) were housed under standard conditions with ad libitum access to pellet food and water. After 1 week of acclimatization, mice were divided into three groups of seven mice each and were injected i.p. with either isotonic saline solution (noninfected control mice), $2 \times 10^{6} \mathrm{P}$. berghei K173 (PbK)-infected erythrocytes (non-CM) or $10^{6} \mathrm{PbA}$-infected erythrocytes (CM), as previously described. ${ }^{38-41}$ The inoculum number was greater for PbK because this prevents the occurrence of $\mathrm{CM}$ in C57BL/6 mice. ${ }^{39}$ Age-matched BALB/c mice, housed under similar conditions, received $10^{6} \mathrm{PbA}$-infected erythrocytes and served as another non-CM control group. Comparisons were made on days 7 and 8 after infection, at which time peripheral parasitemia was similarly low (mean, $4.8 \%$ to $10.4 \%$ ) in all groups, thereby ruling out any confounding factors caused by global hypoxia secondary to anemia. Mice were observed daily for the appearance of $\mathrm{CM}$-associated neurologic signs. Parasitemia was measured during infection by counting at least 500 erythrocytes in thin blood smears.

Female, 5-week-old, C57BL/6 mice (Taconic Europe A/S, Ejby, Denmark) were divided into four groups of five mice each. Two groups were infected i.p. with $10^{4} \mathrm{PbA}$ infected erythrocytes transferred from one in vivo passage as previously described, ${ }^{35}$ and two groups received a similar volume $(200 \mu \mathrm{L})$ of isotonic saline solution i.p. On days 4 through 7 after infection, infected and noninfected mice received either $5000 \mathrm{U} / \mathrm{kg}$ recombinant human EPO (Eprex; Janssen-Cilag Pty., Ltd., Schaffhausen, Switzerland) or $200 \mu \mathrm{L}$ sterile isotonic saline solution. Mice were observed daily for neurologic signs, and parasitemia was measured using flow cytometry. ${ }^{42}$ PARP$1^{-1-}$ mice, generated on a C57BL/6 background, ${ }^{43}$ were provided by Dr. Nicolas Gleichenhaus (Nice, France). Eight female and 4 male PARP $-1^{-1-}$ mice were included in the study and were compared with 10 female and 9 male agematched (31 to 43 weeks) C57BL/6 wild-type (WT) mice. Knockout and WT mice were infected with $10^{6} \mathrm{PbA}$-infected erythrocytes. The described experimental setups enabled us to address whether hypoxia occurred in two $\mathrm{CM}$ models (PbA-infected CBA and C57BL/6 mice), two non-CM models (PbA-infected BALB/c mice and high-dosage PbK-infected CBA mice), and cytopathic hypoxia (PARP-1 ${ }^{-1-}$ mice). Survival was assessed twice daily.

All experiments complied with Australian, Danish, and European guidelines for animal research and were approved by the respective national or state boards for animal studies.

\section{Tissue Processing}

For detection of hypoxia at a comparable time point, all mice were euthanized in an experiment when susceptible mice exhibited clinical signs of $\mathrm{CM}$. All PbA-infected $\mathrm{CBA}^{7}$ and $\mathrm{C} 57 \mathrm{BL} / 6^{5}$ mice demonstrated signs of $\mathrm{CM}$ at days 7 and 8 after infection, respectively, and most of these mice had entered the terminal phase of murine CM. Signs of CM included ruffled fur, loss of coordination, fitting, ataxia, coma, and body temperature lower than $32^{\circ} \mathrm{C}$. Body temperature lower than $32^{\circ} \mathrm{C}$ was considered a proxy for a terminal outcome of the infection, as previously described. ${ }^{35,44}$ On the day of euthanasia, mice were first briefly anesthetized using isoflurane (Baxter Healthcare Corp., Deerfield, IL). Packed cell volume was measured in PbK-infected mice after high-speed centrifugation of blood collected in capillary tubes. During anesthesia, mice were injected i.v. retro-orbitally with $80 \mathrm{mg} / \mathrm{kg}$ pimonidazole $\mathrm{HCl}$ (Hypoxyprobe-1 kit; HPI, Inc., Burlington, MA) and 15 mg/kg Hoechst 33342 (Catalog No. H3570; Invitrogen Corp., Carlsbad, CA) diluted in PBS (total volume, $300 \mu \mathrm{L}$ ), the latter to validate the success of the i.v. injection. Mice 
were allowed to recover, and the solution was left circulating for 30 minutes before euthanasia via cervical dislocation under deep isoflurane anesthesia. The brain was removed quickly, split sagittally, and immersion-fixed in formalin for 24 hours at room temperature before transfer to $70 \%(\mathrm{v} / \mathrm{v})$ ethanol. Tissue was paraffin-embedded automatically using a Histokinette (Shandon, Inc., Pittsburgh, PA) and cut into $5-\mu \mathrm{m}$ thin sagittal sections and $30-\mu \mathrm{m}$ thick sections for Z-stacks.

\section{Immunohistochemistry}

Sections were cleaned of paraffin and rehydrated according to standard procedures. Heat-induced epitope retrieval was performed by boiling sections in citrate buffer $(\mathrm{pH} 6)$ in a microwave oven. Endogenous peroxidase activity was quenched via incubation in $0.5 \%(\mathrm{w} / \mathrm{v}) \mathrm{H}_{2} \mathrm{O}_{2}$ (diluted from $30 \% \mathrm{H}_{2} \mathrm{O}_{2}$; Sigma-Aldrich Corp., St. Louis, MO) dissolved in Tris-buffered saline solution with $0.5 \%$ (v/v) Tween-20 (Merck KGaA, Darmstadt, Germany). Nonspecific binding was blocked using serum-free protein block (Catalog No. X0909; Dako A/S, Glostrup, Denmark). Primary antibodies used included mouse antipimonidazole (50× dilution; HPI, Inc.) and mouse antiHIF-1 $\alpha$ (600X dilution; Catalog No. ab1; Abcam, Inc., Cambridge, MA). Primary antibodies were diluted in 10\% (v/V) goat serum (In Vitro A/S, Fredensborg, Denmark) and incubated overnight at $4^{\circ} \mathrm{C}$. Primary antibodies were detected using a biotinylated goat anti-mouse secondary antibody (200× dilution; Catalog No. B8774; Sigma-Aldrich Corp.). Biotinylated antibody was labeled using an avidin-biotin-peroxidase complex according to the manufacturer's recommendations (Vectastain ABC kit; Cata$\log$ No. PK4000; Vector Laboratories, Inc., Burlingame, $\mathrm{CA}$ ) and was visualized using 3,3-diaminobenzidine tetrahydrochloride tablets (Kem-En-Tec Diagnostics A/S, Taastrup, Denmark) dissolved in Tris-buffered saline solution-0.5\% Tween 20 with $0.015 \% \mathrm{H}_{2} \mathrm{O}_{2}$ (Sigma-Aldrich Corp.). Sections were counterstained using Mayer's hematoxylin (VWR International ApS, Herlev, Denmark) before mounting. Chromogenically stained samples were visualized using an Imager.Z1 microscope fitted with an AxioCam MRc5 Camera (Carl Zeiss Microlmaging $\mathrm{GmbH}$, Göttingen, Germany).

To assess the co-localization of pimonidazole reactivity with a specific cell type, anti-pimonidazole was co-incubated overnight with rabbit anti-glial fibrillary acidic protein (250× dilution; Catalog No. Z334; Dako A/S) for co-localization with astroglia. The primary antibodies were detected using goat anti-mouse IgG-Alexa 568 (1000x dilution; Catalog No. A11031; Invitrogen Corp.) and goat anti-rabbit IgG-Alexa 488 (1000× dilution; Catalog No. A11034; Invitrogen Corp.). For neuronal colocalization, the anti-pimonidazole was first incubated alone overnight, detected using goat anti-mouse IgGAlexa, and incubated for 40 minutes at room temperature with mouse anti-neuronal nuclei-Alexa 488 (100x dilution; Catalog No. MAB377X; Chemicon, Milipore Corp., Billerica, MA). For labeling of vessels, a fluorescein isothiocyanate-conjugated tomato lectin (100X dilution; Catalog No. FL-1171; Vector Laboratories, Inc.) was in- cubated simultaneously with the primary antibody. Nuclei were labeled using DAPI $(20,000 \times$ dilution; Catalog No. D1306; Invitrogen Corp.).

Low-magnification fluorescence microscopy was performed using an Olympus IX-71 equipped with an F-view CCD camera (Olympus Corp., Tokyo, Japan) illuminated with a mercury burner. Confocal immunofluorescence microscopy was performed using a Nikon TE 2000E Eclipse with $60 \times$ numerical aperture 1.4 Apoplan oil immersion objective lens (Nikon Instruments, Inc., Melville, NY), with gain adjusted for each laser (408 nm, 450/35; $488 \mathrm{~nm}$, 515/30; and $543 \mathrm{~nm}, 605 / 75)$. Optical sectioning was performed in 600-nm increments. Standard negative control staining, without any primary antibody, was performed simultaneously for each primary antibody.

\section{Quantification of Immunopositive Cells}

All slides were randomized, blinded, and assessed using digital image analysis by one individual (C.H.). The degree of hypoxia was assessed by thresholding the staining intensity for pimonidazole-labeled areas in various parts of the brain including the olfactory lobe, cortex, corpus callosum, hippocampus, thalamus, hypothalamus, cerebellum, midbrain, pons, and medulla. Photographs were taken at identical settings using an RGB filter at 200× magnification with $2 \times 2$ mosaic function to increase the area sampled (area per micrograph, 1.456 $\mathrm{mm}^{2}$ ). If the region did not fill the entire frame (eg, when tissue boundaries and ventricles were included), these areas were cropped using ImageJ software (version 1.43I; National Institutes of Health, Bethesda, MD). The segmentation plug-in (ImageJ) was used to perform color-based thresholding on the brownish diaminobenzidine precipitation. Thresholding of the images was performed by sampling tissue with positive staining repeatedly in various areas and sections. From these randomly chosen areas, it was possible to set hue (stop), saturation (pass), and brightness (pass), which convincingly differentiated intensely stained tissue from unstained tissue and artifacts. The filtered image was converted to eight-bit gray scale and thresholded in a manner similar to that previously described. ${ }^{45}$ For presentation purposes, the thresholded areas have been normalized to the mean area of noninfected mice.

\section{Stereology}

A systematic uniform random sampling principle was used for assessment of HIF- $1 \alpha$-positive cells. ${ }^{46}$ The number of HIF- $1 \alpha$-positive cells was assessed from a total of at least 16 (range, 16 to 21) micrographs per sagittal section from random parts of the brain. All images were obtained at $200 \times$ magnification with deformation on the $x$ axis $2000 \mu \mathrm{m}$ and on the $\mathrm{y}$ axis $2000 \mu \mathrm{m}[\mathrm{A}($ sample $)=4$ $\mathrm{mm}^{2}$ ] using a motorized stage (piezodrive; Märzhäuser Wetzlar GmbH \& Co. KG, Wetzlar, Germany). The area of the field of vision [A(frame)] was $0.364 \mathrm{~mm}^{2}$, yielding a sampling fraction of $A$ (sample)/A(frame) of approximately 11. The number of cells was calculated from $N=\Sigma Q^{-} \times A($ sample $) / A($ frame $) \times$ corners in tissue/ 
(micrographs sampled $\times 4$ ), where $N$ is the total number and $\Sigma Q^{-}$is the counted number (modified from Andersen et al. ${ }^{47}$ ). The number of corners in tissue divided by the number of micrographs times 4 was used as a correction factor, taking into account that tissue may not completely cover the area of sampled micrographs. It was noted whether the HIF- $1 \alpha$-positive cells were endothelial cells, neurons, glial cells, or cells in circulation on the basis of morphologic characteristics. Flat cells lining vessels were termed endothelial cells; cells with large round nuclei were termed neurons; smaller ovoid, flat, or round nuclei were termed glial cells; and nucleated cells trapped inside the vessels were leukocytes.

\section{Statistical Analysis}

Groupwise comparisons were performed using one-way analysis of variance and post hoc tests (Welch test) for parametric data. Kruskal-Wallis and appropriate post hoc tests were used for non-parametric data. Survival analyses were performed using a log rank test. All statistical analyses were performed using $\mathrm{R}$ for Windows (version 2.10.1; http://www.r-project.org). $P<0.05$ was considered statistically significant.

\section{Results}

\section{Experimental Models and Outcome}

Use of different inbred mouse strains and murine parasite lines enabled comparison of animals with and without $\mathrm{CM}$. Parasitemia progressively increased in all experiments, although to a different extent (repeated-measures analysis of variance, $P=0.001$; Figure 1). However, terminal parasitemia was not significantly different between the groups (analysis of variance, $P=0.061$; Figure 1). Clinical manifestations of $C M$ were observed only in PbA-infected CBA mice and C57BL/6 mice. CBA mice

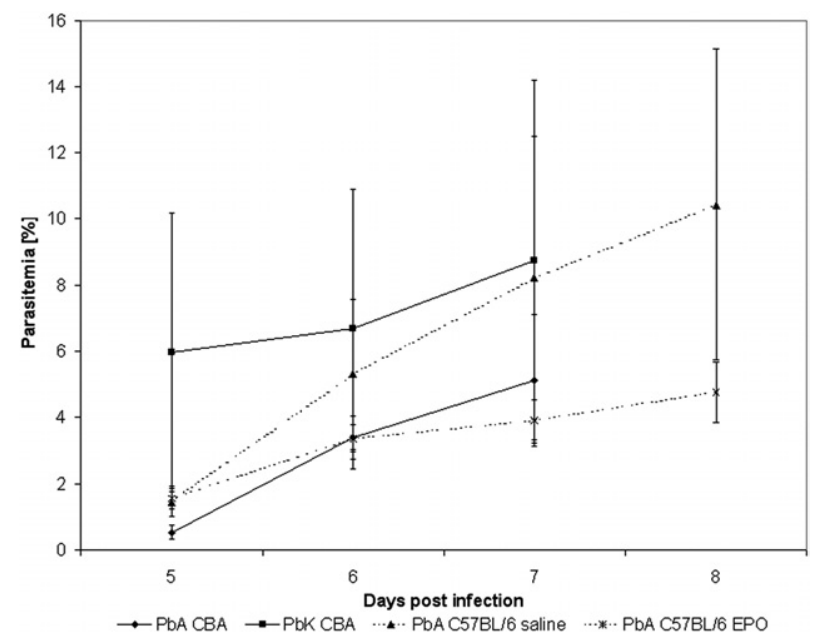

Figure 1. Parasitemia in experimental groups. The parasitemia was calculated from Diff-Quick-stained thin blood smears at days 5, 6, and 7 after infection in CBA mice and at flow cytometry in $\mathrm{C} 57 \mathrm{BL} / 6$ mice. The number of mice in the two infections in CBA mice was 7 at each time point, and 5 in the $\mathrm{C} 57 \mathrm{BL} / 6$-infected mice. Data are from two separate experiments. died on day 7 after infection, with low parasitemia, whereas C57BL/6 died on day 8 after infection, with notably higher parasitemia (mean $\pm \mathrm{SD}, 5.1 \% \pm 1.9$ versus $10.4 \% \pm 4.7 ; P=0.0289)$. PbK-infected CBA mice demonstrated parasitemia comparable to that in C57BL/6 mice $(8.8 \% \pm 5.4 ; P=0.58)$ but exhibited no signs of CM. Packed cell volume in PbK-infected mice was $0.35 \pm$ 0.04. In PARP $^{-1-}$ and WT mice, parasitemia at the time of death was similar: $6.4 \% \pm 0.70$ versus $6.3 \% \pm 1.2$ (Welch test, $P=0.83$ ) and comparable to that in moribund C57BL/6 mice euthanized at day 8 in other experiments (Welch test, $P=0.12$ and $P=0.13$ ).

\section{Hypoxia Detection at the Cellular Level}

Pimonidazole $\mathrm{HCl}$ was injected i.v. to detect hypoxic areas. Few areas and cells seemed to be hypoxic in noninfected mice (Figure 2, A and D). In non-CM, ie, in PbK-infected CBA mice (Figure 2, $\mathrm{B}$ and $\mathrm{E}$ ) and in $\mathrm{PbA}$ infected BALB/C mice (data not shown), some cells stained positive for hypoxia. The cells were scattered and non-uniformly distributed. In both $\mathrm{CM}$ models, ie, PbAinfected CBA and C57BL/6 mice, the number of positive cells was visibly higher, and cells were often grouped in multicellular foci. Moreover, in CM mice, the intensely labeled cells often were surrounded by areas of lowintensity intercellular and intracellular staining (Figure 2, C, F, and I, and Figure 3). Staining was also localized perivascularly (Figure 2, C and F; see also Supplemental Video S1 at http://ajp.amjpathol.org). The degree of hypoxia was assessed from binary masked chromogenic images from different areas of the brain in a sagittal view covering the entire brain (Figure 4, D-G). A groupwise comparison revealed highly significant differences (Kruskal-Wallis test, $P<0.001$; Figure $2 \mathrm{~J}$ ), and CM mice demonstrated an approximately fivefold higher degree of pimonidazole reactivity than did non-CM mice. Post hoc tests revealed that noninfected and $\mathrm{PbA}$-infected mice, in particular, differed in level of hypoxia $(P<0.001)$. Non-CM PbK-infected mice also demonstrated significantly more staining than did noninfected mice $(P=$ 0.013), although significantly less than $\mathrm{PbA}$ mice $(P=$ 0.0028). In C57BL/6 mice infected with PbA (CM) (Figure 3 , saline solution-treated $\mathrm{PbA}$ ), the staining pattern and intensity were similar to those in $\mathrm{PbA}$-infected CBA mice despite less parasitemia, and these mice demonstrated significantly more staining than did noninfected mice (Wilcoxon test, $P<0.001$; Figure 3D).

From this generalized approach, we proceeded to assess whether the differences were restricted to particular brain regions. A significant difference in pimonidazole binding was observed in the corpus callosum (Figure 2K; Kruskal-Wallis test, $P=0.028$; noninfected versus $\mathrm{PbA}$, $P=0.024$ ), the medulla (data not shown; $P=0.048$ ), the midbrain (Figure 2L; $P=0.032$; noninfected versus $\mathrm{PbA}$, $P=0.021$ ), the pons (Figure 2M; $P=0.011$; noninfected versus $\mathrm{PbA}, P=0.0082$ ), and the olfactory lobe (data not shown; $P=0.041)$. In contrast, no significant difference was observed in the cerebellum $(P=0.35)$, the cortex $(P=0.31)$, the hippocampus $(P=0.66)$, the hypothalamus $(P=0.48)$, or the thalamus $(P=0.80)$. The staining 
A

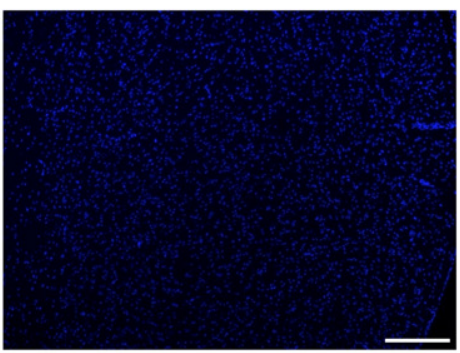

D

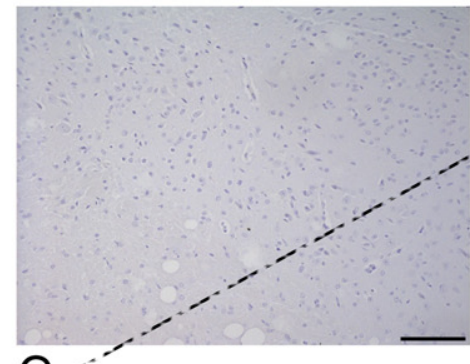

G.

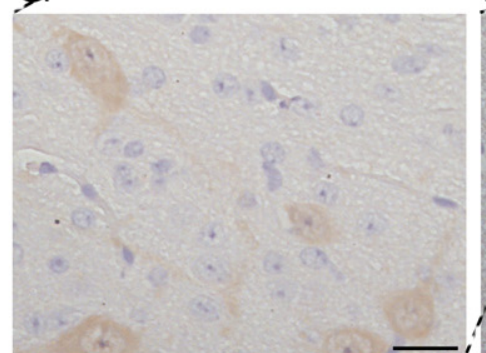

J

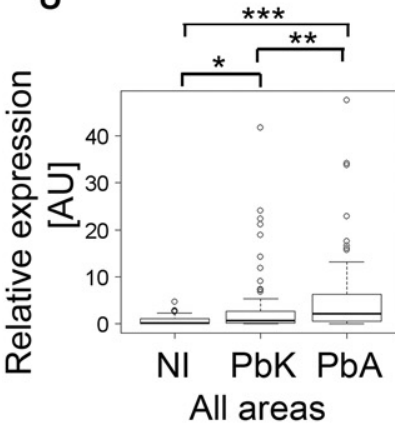

B

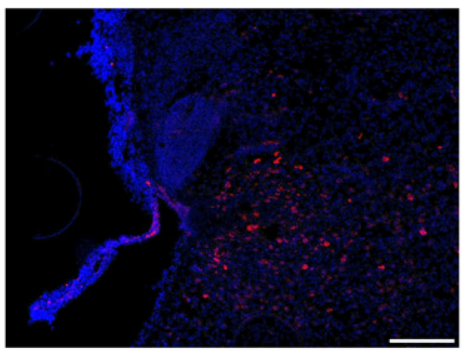

E
C

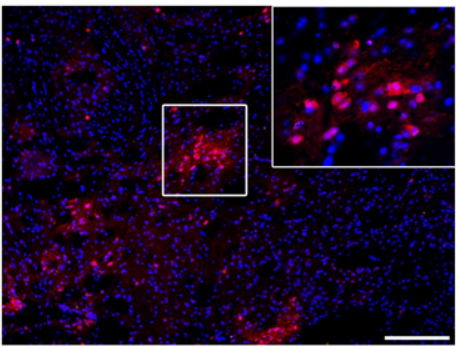

$\mathrm{F}$

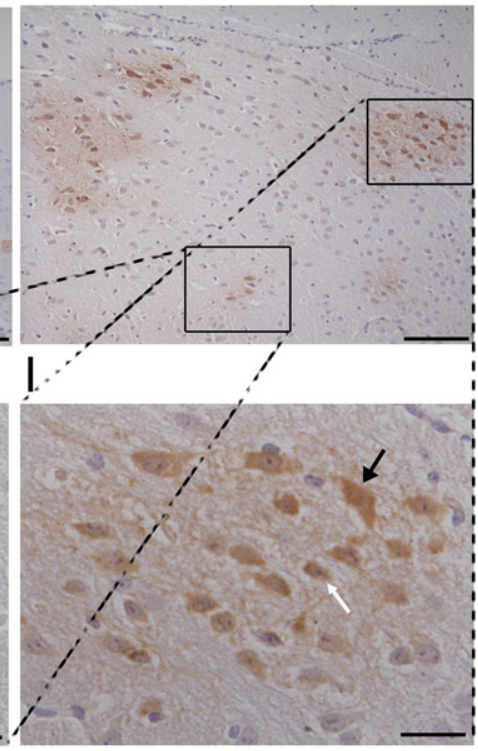

M
$\mathrm{K}$

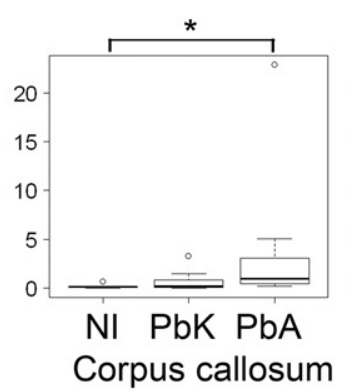

L

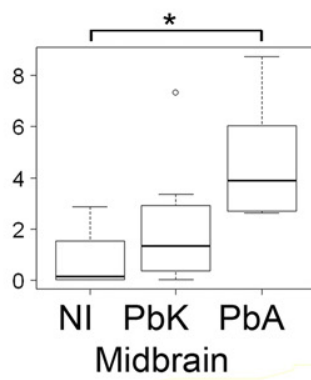

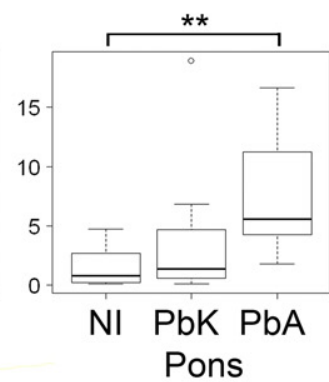

Figure 2. Fluorescent representations of pimonidazole binding in uninfected (A), PbK-infected (B), and PbA-infected (C) CBA mice. Images are representative of results from the noninfected mice in each group at day 7 after infection. DAPI labels nuclei blue, and antibodies detecting pimonidazole adducts emit light in the red spectrum. The area framed by the white box is enlarged in the upper right corner in C. Chromogenic representations of pimonidazole binding in uninfected (D), PbK-infected (E), and PbA-infected $(\mathbf{F})$ mice. The framed area in $\mathbf{E}$ is shown at higher magnification in $\mathbf{G}$, and for $\mathbf{F}$, the areas are magnified in $\mathbf{H}$ and $\mathbf{I}$. Staining shows positively labeled cells $(\mathbf{G}$ and $\mathbf{H})$ and cells surrounded by smears of labeling (I). In $\mathbf{I}$, distinct cells can be observed, including an astrocyte-like cell (white arrow) and a neuron-like cell (black arrow). Scale bars: $200 \mu \mathrm{m}(\mathbf{A}-\mathbf{C}$, but not inserts); $100 \mu \mathrm{m}$ (D-F); $25 \mu \mathrm{m}$ (G-I). Quantification of staining is represented for selected regions in boxplots. J: All areas/total demonstrated a significant increase in PbA-infected mice $(P<0.001)$ and $\mathrm{PbK}$-infected mice $(P=0.013)$ compared with noninfected mice. PbA-infected mice demonstrated significantly higher levels of hypoxia than did PbK-infected mice $(P=$ $0.0028)$. K: In the corpus callosum, PbA-infected mice demonstrated significantly more hypoxia than did noninfected mice $(P=0.024)$, and likewise in the midbrain $(\mathbf{L})(P=0.021)$ and pons $(\mathbf{M})(P=0.0082)$. Values are given as normalized to noninfected mice. The boxplots show the median as a line, interquartile hinges, and the whiskers encompass values $1.5 \times$ from the interquartile range (Tukey test). Open circles indicate outliers. ${ }^{*} 0.05>P>0.01,{ }^{* *} 0.01>P>0.001$, **** $P<0.001$ using the Wilcoxon rank test.

was regional within each individual infected mouse; thus, one mouse did not necessarily demonstrate pronounced staining in the pons, medulla, and olfactory lobe. The low-intensity staining was specific inasmuch as it was observed only in CM mice. This staining pattern was similar in fluorescent and chromogenic detection and, thus, could not be ascribed to endogenous biotin, peroxidase activity, or autofluorescence. Thus, it reflected hypoxia, albeit at a slightly lower grade than that observed in some single large cells. The detection and assessment of cerebral hypoxia was demonstrated to be reproducible in independent experiments. 

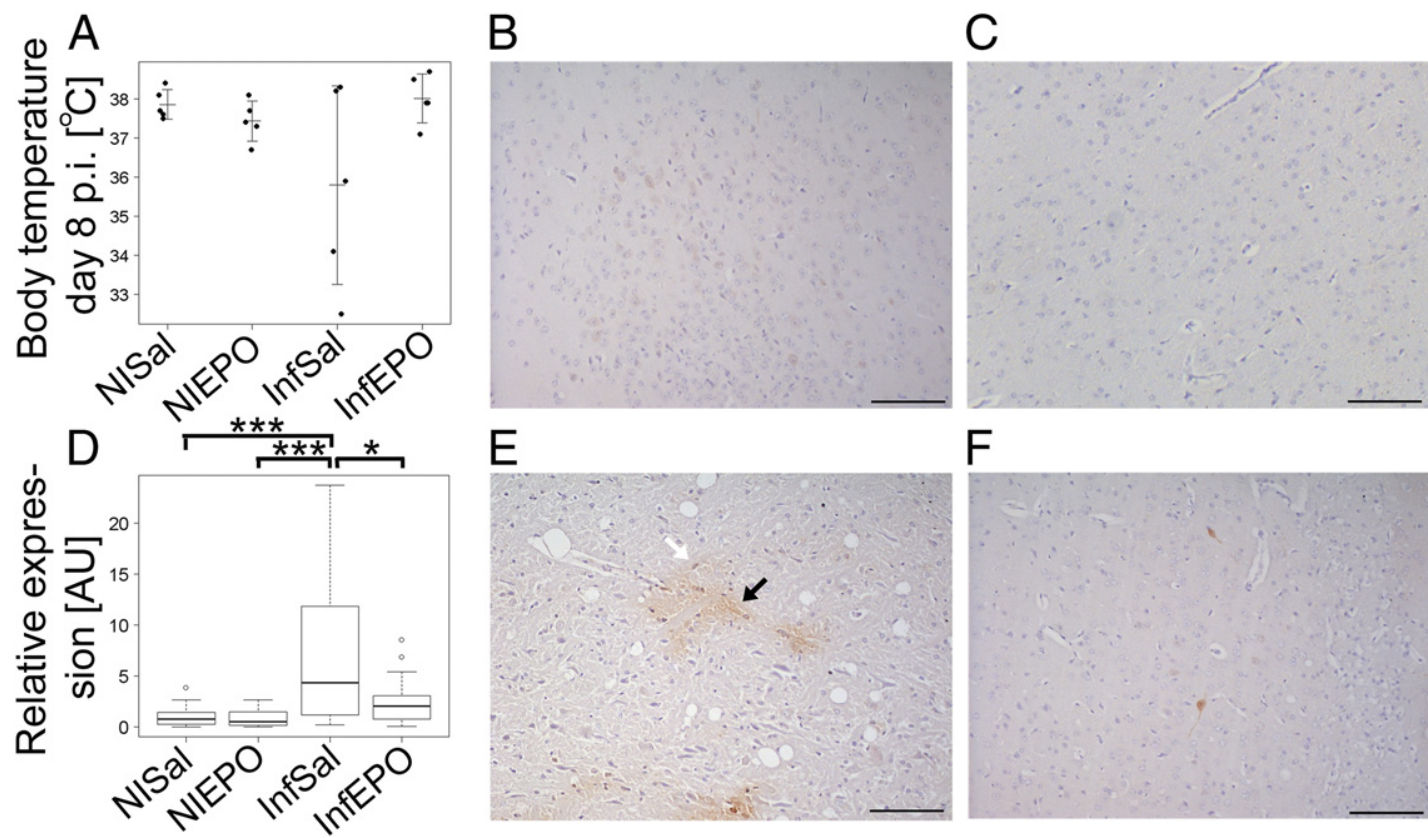

\section{$\mathrm{F}$}

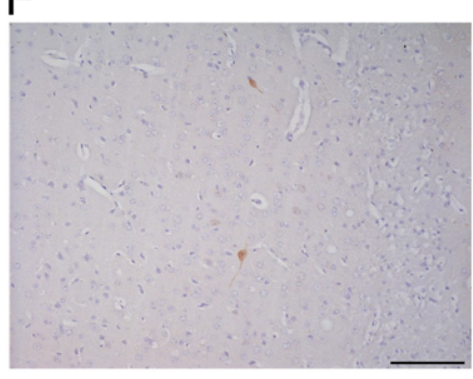

Figure 3. A: EPO treatment reduces the risk of CM, which can be assessed by measuring body temperature. Quantifications of the overall distribution of pimonidazole adducts are depicted in a boxplot (D) expressed relative to saline solution-treated noninfected mice. PbA-infected mice demonstrated a significantly higher level of hypoxia than did EPO-treated infected mice $(P=0.015)$ and noninfected mice $(P<0.001)$. Boxplots show the median as a line, interquartile hinges, and whiskers encompass values $1.5 \times$ from the interquartile range (Tukey test). Circles indicate outliers. ${ }^{*} 0.05>P>0.01,{ }^{* * * *} P<0.001$ using the Wilcoxon rank test. Representative micrographs depict pimonidazole staining in saline solution-treated nonfected (B), EPO-treated noninfected (C), saline solution-treated PbA-infected (E), and EPO-treated PbA-infected (F) mice. Black arrow indicates a cell with neuron-like structure. White arrow indicates a glial-like cell. Scale bars: $100 \mu \mathrm{m}$.

\section{Cellular Localization of Pimonidazole Reactivity Using Fluorescent Labeling}

To try to identify the cell types affected by hypoxia, we performed double staining for neurons and astrocytes, respectively, together with pimonidazole. As noted in the representative micrographs, pimonidazole staining using fluorescence was detectable in neurons but was not visible in astrocytes (Figure 5, A and B, respectively). This staining pattern was compared with the observed cell architecture at chromogenic staining (Figures 2 and 3). In both of these figures, positively staining single cells with astrocyte-like architecture are visible, whereas they were not visible on fluorescent images. Thus, chromogenic

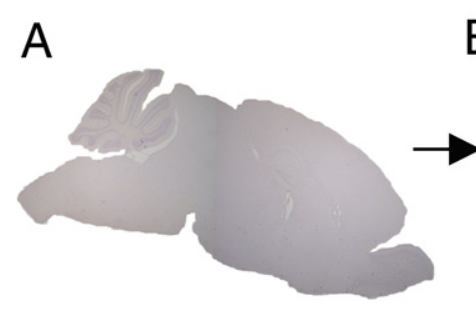

B

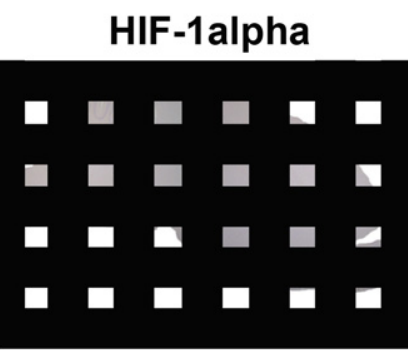

$\stackrel{\downarrow}{\downarrow}$ Hypoxy-probe
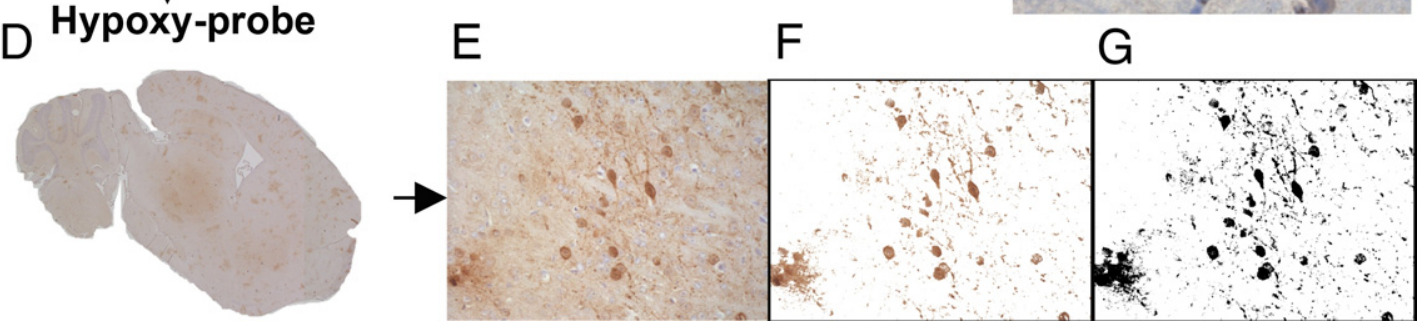

$\mathrm{F}$
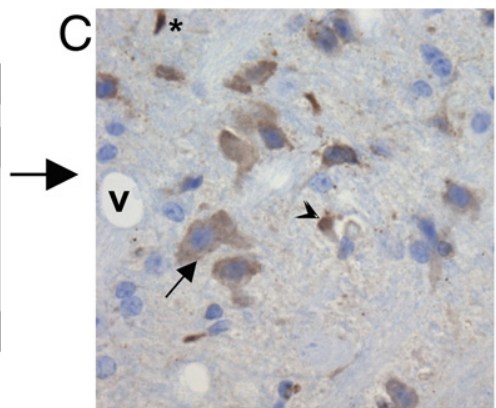

G

Figure 4. Approaches to assessment of tissue hypoxia. A: Tissue was cut in sagittal sections. B: For HIF-1 $\alpha$, the fractionator principle was applied, only counting cells in a predetermined fraction of the tissue. C: Each micrograph was assessed for HIF-1 $\alpha$ expression, and the cellular subset was noted. V indicates the vessel lumen, and nucleated cells trapped intravascularly were noted for being HIF- $1 \alpha$-positive, if observed. Asterisk indicates a glial cell, arrowhead denotes an endothelial cell, and arrow indicates a neuron. D: For pimonidazole reactivity, a multifocal staining pattern was observed in CM mice. To assess the degree of hypoxia in each region of interest $(\mathbf{E})$, the image was color thresholded $(\mathbf{F})$ and converted to a binary image $(\mathbf{G})$. 

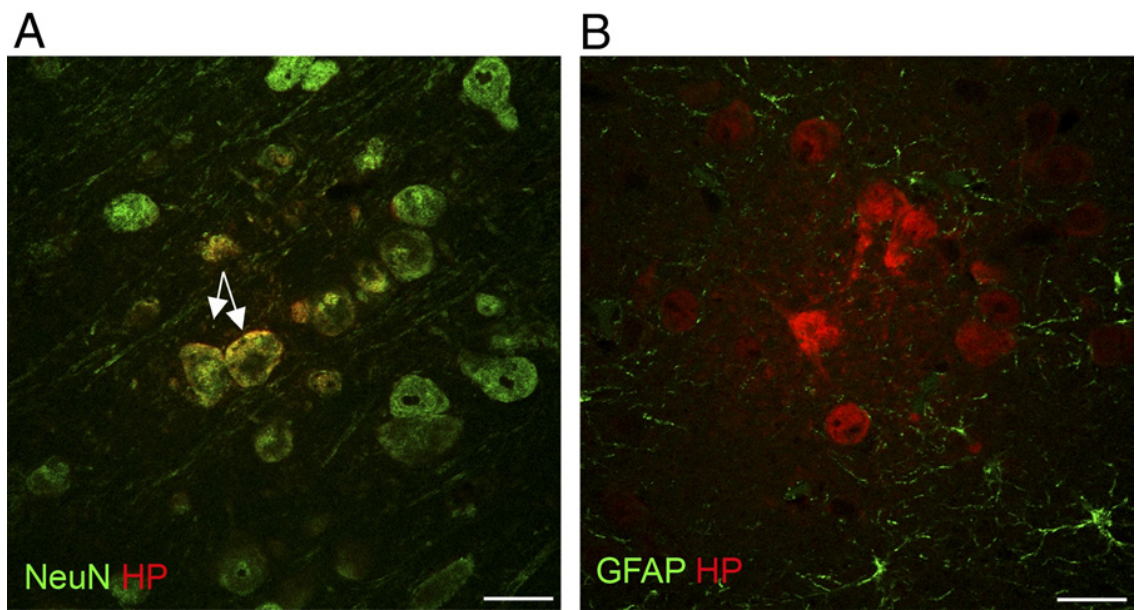

Figure 5. Double immunofluorescence of pimonidazole (HP) binding and neurons (NeuN) (A) and astrocytes (GFAP) (B) at day 7 after infection. NeuN labels neuronal nuclei and the perinuclear area. Arrows denote pronounced co-localization of areas in which both neurons and pimonidazole are present. When staining for astrocytes, co-localization is not observed. Scale bars: $25 \mu \mathrm{m}$.

staining seems to be more sensitive than fluorescent labeling for detection of hypoxia under our experimental conditions. In PbK-infected mice without CM, only a few neurons were positive for hypoxia (Figure 2G).

\section{Increased Level of HIF-1 $\alpha$ Expression in PbA-Infected Mice}

Similar to pimonidazole reactivity, the level of $\mathrm{HIF}-1 \alpha$ was significantly increased in infected mice (Figure 6). However, the staining pattern for HIF-1 $\alpha$ was different from that for pimonidazole binding. It was more common to find single or small groups of HIF- $1 \alpha$-positive cells in the same area (Figure 6, A-C). Clusters of positive cells were also detected, but only in PbA-infected mice (Figure 6, D-F). There was a significant difference between the groups in the number of endothelial cells that stained positive for HIF-1 $\alpha$ (Figure 6G; analysis of variance, $P=$ 0.031). The number of HIF- $1 \alpha$-positive endothelial cells in $\mathrm{PbA}$-infected mice was larger; however, there was only borderline significance when compared with noninfected mice (Welch test, $P=0.05$ ), and no difference when compared with PbK-infected mice (Welch test, $P=$ 0.069). There were no statistically significant differences between the number of HIF-1 $\alpha$-positive glial cells (Figure $6 \mathrm{~J}$; analysis of variance, $P=0.31$ ), neurons (Figure 6l; analysis of variance, $P=0.45)$, or intravascular cells in the various groups (Figure 6; analysis of variance, $P=$ 0.62). Primarily glial cells with astrocyte-like architecture, but also microglial-like cells were HIF- $1 \alpha$-positive. Clusters of HIF-1 $\alpha$-positive cells (Figure 6, D-F) were observed only in PbA-infected mice.

\section{PARP-1 ${ }^{-/-}$Mice Are Not Protected Against CM}

Mice with a PARP-1 ${ }^{-1-}$ genotype demonstrate less inflammation and exhibit improved survival in a model of septic shock, ${ }^{48}$ although this genotype is more susceptible to DNA damage. ${ }^{49}$ To assess whether cytopathic hypoxia was essential for development of murine CM, $\mathrm{PbA}$ infection in PARP-1 ${ }^{-1-}$ knockout mice was com- pared with that in C57BL/6 WT mice. There was no statistically significant difference in survival between PARP$1^{-1-}$ and WT mice $(P=0.15)$ (Figure 7$)$, and the infection was clinically indistinguishable in WT and knockout mice. Both knockout and WT moribund mice exhibited signs of $\mathrm{CM}$, and most died on days 7 to 9 after infection.

\section{EPO Therapy Improves Survival and Decreases Hypoxia}

To assess whether ameliorative treatment with EPO also reduced cerebral hypoxia, we included four groups of mice: those with or without $\mathrm{PbA}$ infection and those with or without EPO therapy. Similar to findings of previous studies, ${ }^{35}$ EPO therapy significantly improved survival (analysis of variance, $P=0.01$; Figure $3 \mathrm{~A}$ ) and reversed the clinical symptoms of CM. EPO therapy reduced tissue hypoxia (Figure 3) in comparison with saline solutiontreated mice with CM (Kruskal-Wallis test, $P<0.001$; Figure 3, B-F). Post hoc tests revealed no statistically significant difference between the two uninfected groups ( $P=0.80$; Figure $3, \mathrm{~B}$ and $\mathrm{C})$, whereas infected saline solution-treated mice (Figure 3E) demonstrated significantly more staining than did noninfected mice $(P<$ $0.001)$ and infected EPO-treated mice $(P=0.015$; Figure 3F). PbA-infected EPO-treated mice did not differ significantly from the noninfected groups in the amount of pimonidazole staining ( $P=0.54$ for both groups).

\section{Discussion}

The present study directly demonstrates the presence of multifocal areas of cerebral hypoxia in two murine models of CM. To our knowledge, this is the first study of its kind and provides strong direct evidence that tissue hypoxia is present in CM. A distinct staining pattern was observed, with marked hypoxia in neuronal somas and widespread low-grade intercellular and intracellular hypoxia. The staining pattern was unrelated to peripheral parasitemia but was closely related to cerebral manifestations. Single cells with astrocyte-like architecture also were hypoxic. This diffuse staining pattern is in accor- 


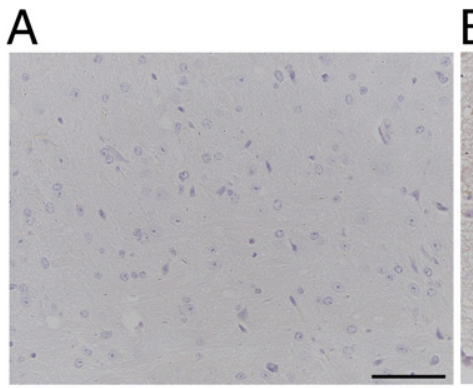

B

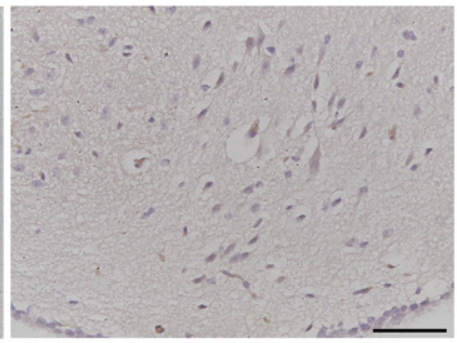

D

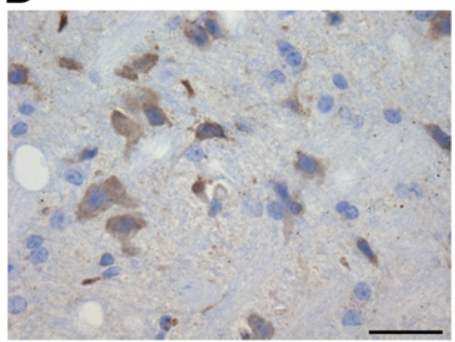

E

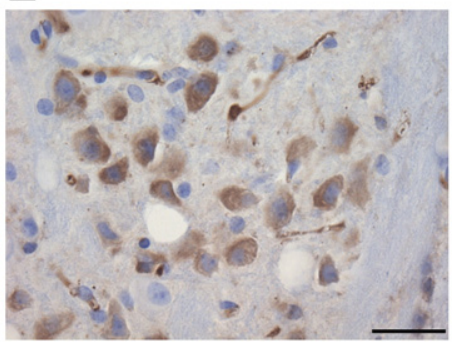

C

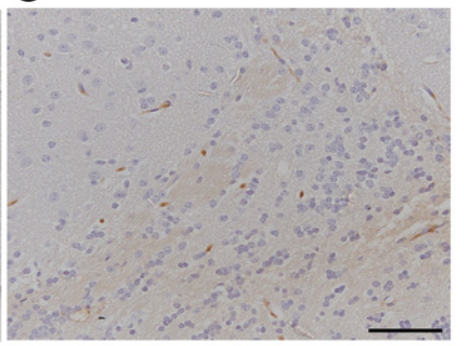

$\mathrm{F}$

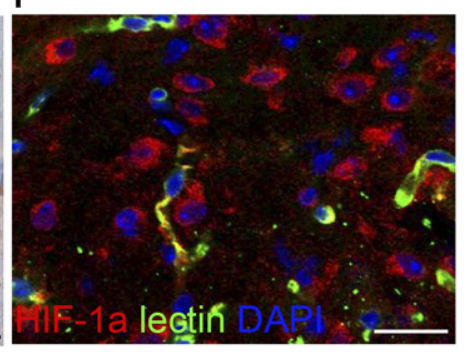

J
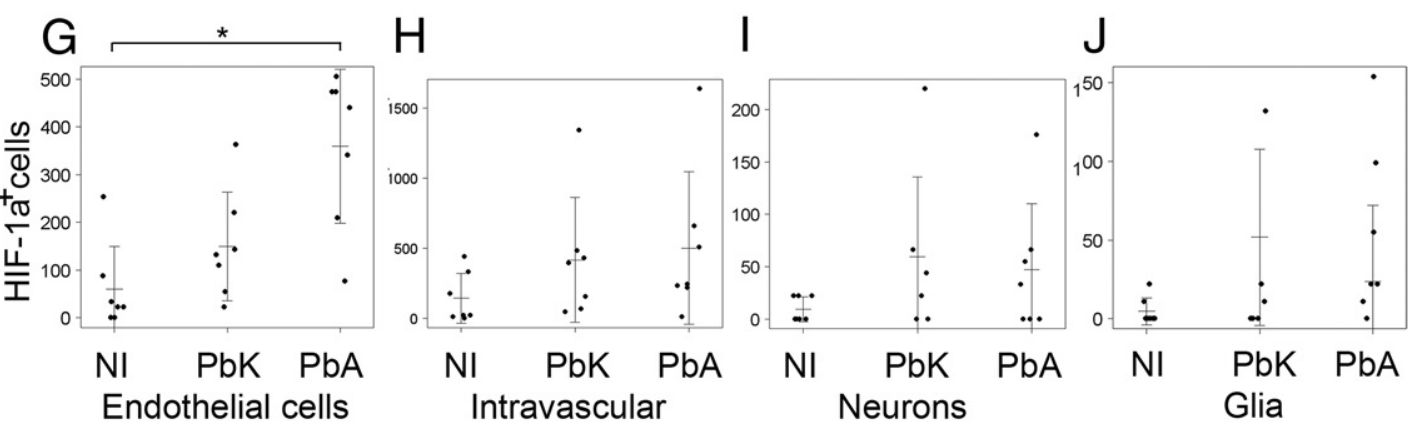

Figure 6. Representative images of HIF-1 $\alpha$ staining in noninfected (A), PbK-infected (B), and PbA-infected (C) mice. Diverse expression in several cell types was observed in patches $(\mathbf{D})$, and pronounced perivascular labeling of neurons was demonstrated in $\mathrm{PbA}$ mice $(\mathbf{E}$ and $\mathbf{F})$. F: Nuclei are blue, vessels are green, and HIF- $1 \alpha$-positive cells are red. Scale bars: $100 \mu \mathrm{m}(\mathbf{A}-\mathbf{C}) ; 50 \mu \mathrm{m}(\mathbf{D}-\mathbf{F})$. Quantifications are visualized in stripcharts for each quantitative trait: G: Endothelial cells. H: Intravascular staining. I: Neurons. J: Glial cells. Horizontal bar indicates the mean, and vertical bars indicate SD. *0.05 $>P>0.01$ using the Wilcoxon rank test.

dance with findings of previously published articles on the use of pimonidazole $\mathrm{HCl}$ as a probe for hypoxic tissue. ${ }^{45,50-53}$ The multifocal hypoxic areas are likely the outcome of cerebral cytoadhesion and vasospasms often seen in murine CM. 2,28,31,32,41,54 In particular, the olfactory lobe and the brainstem were affected with hypoxia.

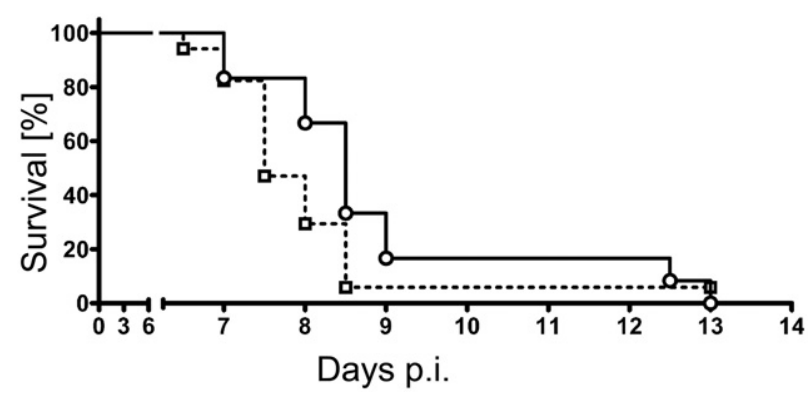

Figure 7. Survival curves of WT and PARP knockout mice. Most mice of both genotypes died of $\mathrm{CM}$ at days 7 to 9 after infection. $\mathrm{PARP}^{-/-}$mice were not protected $(P=0.15)$, although the onset of symptoms seemed to be delayed by approximately 1 day in the PARP knockout genotype. Data for $\mathrm{PARP}^{-/-}$mice are indicated by the filled line and circles, and for PARP WT mice by the dashed line and squares.
The impaired microcirculation is of pathophysiologic relevance owing to impaired oxygen delivery. Even perivascularly, cerebral hypoxia was observed in terminally ill mice with CM. Optical sectioning (Video S1) demonstrated an example of one such area in which hypoxic cells in the brain parenchyma are adjacent to plugged vessels. The extent of cerebral hypoxia detected in CM mice likely causes impaired neuronal communication, ${ }^{53}$ which in turn leads to cerebral debilitation and altered behavior. ${ }^{55}$ A low degree of hypoxia could also be demonstrated as scattered, single, hypoxic cells in non-CM models without clinically obvious neurologic impairment, which suggests that even in the absence of cerebral signs, malaria may affect neural tissue. ${ }^{17}$

A close association was not observed between the hypoxic brain areas detected using pimonidazole binding and the areas that seemed to be hypoperfused in other studies that used magnetic resonance imaging. ${ }^{25}$ One explanation for this could be that the frequent vasospasms observed in murine CM are localized primarily in the cerebral cortex, whereas smaller, yet more severe, focal occlusions in other parts of the 
brain may not be observed on magnetic resonance images.

Cerebral hypoxia is a serious condition that, if not reversed, will lead to severe brain injury. A compensatory increase in cerebral blood flow is the natural response to local hypoxia. This may be another reason why relatively crude measurements of perfusion have yielded conflicting results about blood flow in human CM. Transcranial Doppler ultrasound failed to demonstrate decreased blood flow in human $\mathrm{CM}^{56}$; however, the resolution of the technique may not be sufficient to detect localized foci of hypoperfusion and occlusion. Low resolution has also proved limiting in magnetic resonance imaging in patients with $\mathrm{CM}^{57}$ At a certain point, the compensatory mechanisms can become incapable of maintaining sufficient tissue oxygenation, ${ }^{58}$ and irreversible cell and tissue damage will result. ${ }^{11,59}$ The substantial evidence of similarities between human and murine $\mathrm{CM}^{24,54}$ and the direct and indirect evidence of localized cerebral hypoperfusion in human $\mathrm{CM}^{7,15,16,23,60,61}$ underscore the need to address strategies to reverse cerebral occlusion and hypoperfusion.

In non-CM mice, hypoxia was much less pronounced than in $\mathrm{CM}$ mice, and was confined to neuronal somas. This is most likely because tissue oxygenation is balanced between oxygen supply and metabolic rate. Thus, in conditions of slightly decreased oxygen supply, which is likely in non-CM mice with severe anemia, ${ }^{62}$ neurons may sustain a low degree of hypoxia because of their higher metabolic rate compared with that of glial cells. ${ }^{63,64}$ The hypoxia in non-CM mice could not be explained by reduced microcirculation because the PbK parasites used in the study do not sequester in the microvasculature. ${ }^{65}$ One explanation could be impaired oxygen delivery and carrying capacity, as previously described. ${ }^{66}$ Furthermore, decreased numbers of oxygen-carrying erythrocytes due to anemia also induce expression of hypoxia-associated markers. ${ }^{67}$ When patients with malaria without CM were assessed for retinopathy, retinal whitening was detected, which suggests some degree of hypoperfusion and ischemia in uncomplicated malaria in humans. ${ }^{17}$

HIFs have a key role in hypoxia-induced signaling events. However, HIF- $1 \alpha$ is also up-regulated by proinflammatory cytokines, ${ }^{10,68}$ and, thus, is not solely a marker of hypoxia. Interleukin-1 and tumor necrosis factor are established inducers of $\mathrm{HIF}-1 \alpha,{ }^{68}$ and these cytokines also have a contributory role in murine and human $\mathrm{CM}^{2,14,54}$ During normoxia, HIF- $1 \alpha$ is quickly degraded by ubiquitinylation in the cytosol, whereas hypoxic conditions facilitate the heterodimerization of $\mathrm{HIF}-1 \alpha$ and HIF-1 $\beta$ (constitutively expressed), nuclear translocation, and binding to the hypoxia-responsive elements on downstream targets. ${ }^{10}$ Nuclear translocation was not obvious in the present study inasmuch as most staining was cytosolic. A high level of cytosolic HIF-1 $\alpha$ expression points to increased stabilization of $\mathrm{HIF}-1 \alpha$ and limited nuclear translocation. A high level of cytosolic HIF-1 $\alpha$ has been documented previously during hypoxic stimulation in vitro. ${ }^{69,70}$ We assessed expression at one time point only, and HIF-1 $\alpha$ might be translocated later. In addition to hypoxia, several mediators regulate HIF- $1 \alpha$ expres- sion, stabilization, and degradation. One of those is c-Jun $N$-terminal kinase-1, which increases stabilization in the cytosol. ${ }^{71}$ In relation to cerebral malaria, a recent article demonstrated increased activated c-Jun N-terminal kinase levels in the brain in experimental $\mathrm{CM}^{72}$ In contrast to pimonidazole staining, which was primarily localized in neurons, the HIF- $1 \alpha$-positive cells were predominantly endothelial cells. This discrepancy most likely reflects the two different parameters detected by these markers. Pimonidazole reactivity solely reflects low oxygen tension, whereas $\mathrm{HIF}-1 \alpha$ demonstrates the acute cellular response to hypoxia and inflammation. Because HIF-1 $\alpha$ expression is an important physiologic response to hypoxia, it may be speculated that the low levels of HIF- $1 \alpha$ in tissues with pronounced hypoxia may represent an insufficient response that contributes to development of $\mathrm{CM}$. If some degree of respiratory impairment in the neuronal mitochondria is assumed, this promotes prolyl hydroxylase-dependent degradation of HIF- $1 \alpha$ stability, ${ }^{73}$ which may negatively influence detection. Inasmuch as $\mathrm{HIF}-1 \alpha$ is also involved in a cellular response to inflammation, it is likely that this arm is most heavily affected in the endothelium lining the vessels with increased levels of inflammatory cytokines, ${ }^{54}$ thereby sustaining a detectable response. The method described herein will enable this hypothesis to be addressed further in future studies.

In human brain tissue obtained postmortem, no HIF-1 $\alpha$ expression was observed; however, HIF-2 $\alpha$ was detected in the nuclei and cytoplasm in the vasculature and to a significantly larger extent in $\mathrm{CM}^{74}$ Medana et al. ${ }^{74}$ raised the possibility that local cerebral perfusion may compensate for occlusions caused by sequestering cells in the vascular beds; however, this is to some extent contradicted by the increased levels of $\mathrm{HIF}-2 \alpha$, vascular endothelial growth factor, and DEC-1, all proteins induced by hypoxia. The failure to detect $\mathrm{HIF}-1 \alpha$ probably reflects the heterogeneity of the study population, and in particular the short half-life of HIF-1 $\alpha$, more than its unchanged expression. ${ }^{9}$ Consistent with this interpretation, HIF-2 $\alpha$ is up-regulated for a considerably longer time during prolonged hypoxia and is not considered an acute marker of hypoxia. ${ }^{75}$

One of the most promising adjunctive strategies for CM is EPO, 5,76 which is a strongly hypoxia-regulated cytokine. In the present study, EPO therapy initiated before the onset of neurologic symptoms resulted in a significant decrease in cerebral hypoxia, which coincided with decreased signs of CM. Indeed, EPO reverted tissue hypoxia, as indicated by the pimonidazole technique, to the levels in noninfected mice. EPO is neuroprotective in both cerebral hypoxia and ischemia-reperfusion injury, ${ }^{70,77}$ and, thus, seems to be a promising candidate for adjunctive treatment of $\mathrm{CM}$, in particular with respect to hypoxia. Previous studies have documented that EPO dose-dependently reduces the mortality of murine $\mathrm{CM}^{34,35}$ Studies of endogenous EPO in human CM have yielded conflicting findings. Some authors have suggested that its local expression in the brain is unrelated to $\mathrm{CM},{ }^{78}$ whereas others find it strongly associated with protection against neurologic sequelae in survivors of $\mathrm{CM}^{79} \mathrm{EPO}$ is an anti-apoptotic hormone that protects endothelial 
cells, ${ }^{80}$ thereby conserving BBB function in a stroke model ${ }^{81}$. Another and perhaps more important property of EPO in the context of CM is its stimulatory effect on nitric oxide secretion caused by endothelial nitric oxide synthase, ${ }^{82}$ which improves perfusion under experimental conditions. ${ }^{83}$ The role of nitric oxide in CM has been thoroughly evaluated, and decreased production has been suggested to be important in the pathogenesis of murine and human $\mathrm{CM}^{84,85} \mathrm{In}$ addition, EPO reduces cerebral hypoxia by up-regulating neuronal hemoglobin expression. ${ }^{53}$ In addition to these actions, EPO is also anti-inflammatory. ${ }^{34,35}$ These pleiotropic effects of EPO likely contribute to the improved survival in complex ways. EPO seemed to decrease parasitemia, which might contribute to survival in these mice, although this remains to be established.

PARP-1 is a key enzyme in cytopathic hypoxia. ${ }^{12}$ There was a tendency toward slightly delayed development of $\mathrm{CM}$ in PARP ${ }^{-1-}$ mice; however, this was not significant. It has been hypothesized that cytopathic hypoxia has a significant contributory role in the pathogenesis of $\mathrm{CM} .{ }^{14,26,54}$ We could not confirm this, and in contrast to sepsis, ${ }^{12}$ PARP-1 does not seem to be the driving force for murine $\mathrm{CM}$.

The use of isoflurane as anesthetic also needs to be addressed. In several studies, isoflurane, compared with other anesthetic agents, maintained stable cerebral blood flow and high tissue oxygenation ${ }^{86,87}$ and, thus, does not cause false interpretations of tissue hypoxia. Indeed, the decrease in blood pressure and cerebral perfusion caused by the related anesthetic desflurane has been associated with increased brain oxygenation, ${ }^{88}$ possibly as a result of its vasodilator properties and lower cerebral metabolic rate. ${ }^{86,89} \mathrm{HIF}-1 \alpha$ expression is induced by isoflurane in vitro ${ }^{90}$ and in vivo, and this depends on activation of the extracellular signal-regulated kinases cascade. ${ }^{91}$ These findings were, however, only observed after 30 minutes of isoflurane anesthesia ${ }^{91}$ as opposed to the brief duration in the present study. Thus, anesthesia likely is not the cause of the observed changes.

Pimonidazole-based detection of hypoxia is semiquantitative but has been shown to distinguish hypoxic areas as well as with use of a quantitative enzyme-linked immunosorbent assay-based approach. ${ }^{50}$ Furthermore, IHC enabled us to obtain detailed information about the perivascular expression pattern and to pinpoint neuronal and perivascular hypoxia due to cerebral hypoperfusion. Considered together with the bulk of data on hypoperfusion in murine and human $\mathrm{CM},{ }^{15,17,20,23,25,28,76}$ this new approach seems appropriate for further mechanistic research. The results overall suggest that cerebral hypoperfusion leads to tissue hypoxia in murine $\mathrm{CM}$ and that this is likely a key event in development of acute cerebral disease.

\section{Acknowledgments}

We thank Nicolas Gleichenhaus (Université de Nice-Sophia Antipolis, France) for information about where to purchase PARP-1 knockout mice and Fatima El-Assaad for expertise during i.v. injections.

\section{References}

1. Grau GE, Mackenzie CD, Carr RA, Redard M, Pizzolato G, Allasia C Cataldo C, Taylor TE, Molyneux ME: Platelet accumulation in brain microvessels in fatal pediatric cerebral malaria. J Infect Dis 2003, 187:461-466

2. Combes V, El-Assaad F, Faille D, Jambou R, Hunt NH, Grau GE: Microvesiculation and cell interactions at the brain-endothelial interface in cerebral malaria pathogenesis. Prog Neurobiol 2010, 91:140151

3. Armah H, Dodoo AK, Wiredu EK, Stiles JK, Adjei AA, Gyasi RK, Tettey $Y$ : High-level cerebellar expression of cytokines and adhesion molecules in fatal, paediatric, cerebral malaria. Ann Trop Med Parasitol 2005, 99:629-647

4. Medana IM, Turner GD: Human cerebral malaria and the blood-brain barrier. Int J Parasitol 2006, 36:555-568

5. Maude RJ, Beare NA: Fluorescein angiography findings strengthen the theoretical basis for trialing neuroprotective agents in cerebra malaria. Trends Parasitol 2009, 25:350-351

6. White NJ, Warrell DA, Looareesuwan S, Chanthavanich P, Phillips RE, Pongpaew P: Pathophysiological and prognostic significance of cerebrospinal-fluid lactate in cerebral malaria. Lancet 1985, 1:776-778

7. Warrell DA, White NJ, Veall N, Looareesuwan S, Chanthavanich P Phillips RE, Karbwang J, Pongpaew P, Krishna S: Cerebral anaerobic glycolysis and reduced cerebral oxygen transport in human cerebral malaria. Lancet 1988, 2:534-538

8. Molyneux ME, Taylor TE, Wirima JJ, Borgstein A: Clinical features and prognostic indicators in paediatric cerebral malaria: a study of 131 comatose Malawian children. Q J Med 1989, 71:441-459

9. Jewell UR, Kvietikova I, Scheid A, Bauer C, Wenger RH, Gassmann $\mathrm{M}$ : Induction of HIF-1alpha in response to hypoxia is instantaneous. FASEB J 2001, 15:1312-1314

10. Sharp FR, Bernaudin M: HIF1 and oxygen sensing in the brain. Nat Rev Neurosci 2004, 5:437-448

11. Walshe TE, D'Amore PA: The role of hypoxia in vascular injury and repair. Annu Rev Pathol 2008, 3:615-643

12. Fink MP: Bench-to-bedside review: cytopathic hypoxia. Crit Care 2002, 6:491-499

13. Fink M: Cytopathic hypoxia in sepsis. Acta Anaesthesiol Scand Suppl 1997, 110:87-95

14. Clark IA, Budd AC, Alleva LM, Cowden WB: Human malarial disease: a consequence of inflammatory cytokine release. Malar J 2006, 5:85

15. Beare NA, Harding SP, Taylor TE, Lewallen S, Molyneux ME: Perfusion abnormalities in children with cerebral malaria and malarial retinopathy. J Infect Dis 2009, 199:263-271

16. Maude RJ, Beare NA, Abu SA, Chang CC, Charunwatthana P, Faiz MA, Hossain A, Yunus EB, Hoque MG, Hasan MU, White NJ, Day NP, Dondorp AM: The spectrum of retinopathy in adults with Plasmodium falciparum malaria. Trans R Soc Trop Med Hyg 2009, 103:665-671

17. Essuman VA, Ntim-Amponsah CT, Astrup BS, Adjei GO, Kurtzhals JA, Ndanu TA, Goka B: Retinopathy in severe malaria in Ghanaian children: overlap between fundus changes in cerebral and noncerebral malaria. Malar J 2010, 9:232

18. Beare NA, Glover SJ, Molyneux M: Malarial retinopathy in cerebral malaria. Am J Trop Med Hyg 2009, 80:171

19. Maude RJ, Dondorp AM, Abu SA, Day NP, White NJ, Beare NA: The eye in cerebral malaria: what can it teach us? Trans R Soc Trop Med Hyg 2009, 103:661-664

20. White VA, Lewallen S, Beare NA, Molyneux ME, Taylor TE: Retinal pathology of pediatric cerebral malaria in Malawi. PLoS One 2009, 4:e4317

21. Dondorp AM, Ince C, Charunwatthana P, Hanson J, van KA, Faiz MA Rahman MR, Hasan M, Bin YE, Ghose A, Ruangveerayut R, Limmathurotsakul D, Mathura K, White NJ, Day NP: Direct in vivo assessment of microcirculatory dysfunction in severe falciparum malaria J Infect Dis 2008, 197:79-84

22. Kampfl A, Pfausler B, Haring HP, Denchev D, Donnemiller E, Schmutzhard E: Impaired microcirculation and tissue oxygenation in human cerebral malaria: a single photon emission computed tomography 
and near-infrared spectroscopy study. Am J Trop Med Hyg 1997 , 56:585-587

23. Lewallen S, Bronzan RN, Beare NA, Harding SP, Molyneux ME, Taylor TE: Using malarial retinopathy to improve the classification of children with cerebral malaria. Trans R Soc Trop Med Hyg 2008, 102:10891094

24. Hunt NH, Grau GE, Engwerda C, Barnum SR, van der HH, Hansen DS, Schofield L, Golenser J: Murine cerebral malaria: the whole story. Trends Parasitol 2010, 26:272-274

25. Penet MF, Viola A, Confort-Gouny S, Le FY, Duhamel G, Kober F, Ibarrola D, Izquierdo M, Coltel N, Gharib B, Grau GE, Cozzone PJ: Imaging experimental cerebral malaria in vivo: significant role of ischemic brain edema. J Neurosci 2005, 25:7352-7358

26. Rae C, McQuillan JA, Parekh SB, Bubb WA, Weiser S, Balcar VJ, Hansen AM, Ball HJ, Hunt NH: Brain gene expression, metabolism, and bioenergetics: interrelationships in murine models of cerebral and noncerebral malaria. FASEB J 2004, 18:499-510

27. Sanni LA, Rae C, Maitland A, Stocker R, Hunt NH: Is ischemia involved in the pathogenesis of murine cerebral malaria? Am J Pathol 2001, 159:1105-1112

28. Cabrales P, Zanini GM, Meays D, Frangos JA, Carvalho LJ: Murine cerebral malaria is associated with a vasospasm-like microcirculatory dysfunction, and survival upon rescue treatment is markedly increased by nimodipine. Am J Pathol 2010, 176:1306-1315

29. Polder T, Jerusalem C, Eling W: Topographical distribution of the cerebral lesions in mice infected with Plasmodium berghei. Tropenmed Parasitol 1983, 34:235-243

30. Polder TW, Jerusalem CR, Eling WM: Morphological characteristics of intracerebral arterioles in clinical (Plasmodium falciparum) and experimental (Plasmodium berghei) cerebral malaria. J Neurol Sci 1991, 101:35-46

31. Chang-Ling T, Neill AL, Hunt NH: Early microvascular changes in murine cerebral malaria detected in retinal whole mounts. Am J Pathol 1992, 140:1121-1130

32. Grau GE, Tacchini-Cottier F, Vesin C, Milon G, Lou JN, Piguet PF, Juillard P: TNF-induced microvascular pathology: active role for platelets and importance of the LFA-1/ICAM-1 interaction. Eur Cytokine Netw 1993, 4:415-419

33. Blanco YC, Farias AS, Goelnitz U, Lopes SC, Arrais-Silva WW, Carvalho BO, Amino R, Wunderlich G, Santos LM, Giorgio S, Costa FT: Hyperbaric oxygen prevents early death caused by experimenta cerebral malaria. PLoS One 2008, 3:e3126

34. Kaiser K, Texier A, Ferrandiz J, Buguet A, Meiller A, Latour C, Peyron F, Cespuglio R, Picot S: Recombinant human erythropoietin prevents the death of mice during cerebral malaria. J Infect Dis 2006, 193: 987-995

35. Wiese L, Hempel C, Penkowa M, Kirkby N, Kurtzhals JA: Recombinant human erythropoietin increases survival and reduces neuronal apoptosis in a murine model of cerebral malaria. Malar J 2008, 7:3

36. Arteel GE, Thurman RG, Raleigh JA: Reductive metabolism of the hypoxia marker pimonidazole is regulated by oxygen tension independent of the pyridine nucleotide redox state. Eur J Biochem 1998, 253:743-750

37. Hotchkiss RS, Rust RS, Dence CS, Wasserman TH, Song SK, Hwang $\mathrm{DR}$, Karl IE, Welch MJ: Evaluation of the role of cellular hypoxia in sepsis by the hypoxic marker [18F]fluoromisonidazole. Am J Physiol 1991, 261:R965-R972

38. Grau GE, Piguet PF, Engers HD, Louis JA, Vassalli $\mathrm{P}$, Lambert PH: L3T4+ T lymphocytes play a major role in the pathogenesis of murine cerebral malaria. J Immunol 1986, 137:2348-2354

39. Mitchell AJ, Hansen AM, Hee L, Ball HJ, Potter SM, Walker JC, Hunt $\mathrm{NH}$ : Early cytokine production is associated with protection from murine cerebral malaria Infect Immunol 2005, 73:5645-5653

40. Neill AL, Hunt NH: Pathology of fatal and resolving Plasmodium berghei cerebral malaria in mice. Parasitology 1992, 105(Pt 2):165-175

41. Ma N, Hunt NH, Madigan MC, Chan-Ling T: Correlation between enhanced vascular permeability, up-regulation of cellular adhesion molecules and monocyte adhesion to the endothelium in the retina during the development of fatal murine cerebral malaria. Am J Pathol 1996, 149:1745-1762

42. Hein-Kristensen L, Wiese L, Kurtzhals JA, Staalsoe T: In-depth validation of acridine orange staining for flow cytometric parasite and reticulocyte enumeration in an experimental model using Plasmodium berghei. Exp Parasitol 2009, 123:152-157
43. de Murcia JM, Niedergang C, Trucco C, Ricoul M, Dutrillaux B, Mark M, Oliver FJ, Masson M, Dierich A, LeMeur M, Walztinger C, Chambon P, de Murcia G: Requirement of poly(ADP-ribose) polymerase in recovery from DNA damage in mice and in cells. Proc Natl Acad Sci USA: 1997, 94:7303-7307

44. Curfs JH, Schetters TP, Hermsen CC, Jerusalem CR, van Zon AA, Eling WM: Immunological aspects of cerebral lesions in murine maIaria. Clin Exp Immunol 1989, 75:136-140

45. Jankovic B, Aquino-Parsons C, Raleigh JA, Stanbridge EJ, Durand RE, Banath JP, MacPhail SH, Olive PL: Comparison between pimonidazole binding, oxygen electrode measurements, and expression of endogenous hypoxia markers in cancer of the uterine cervix. Cytometry B Clin Cytom 2006, 70:45-55

46. Larsen JO: Stereology of nerve cross sections. J Neurosci Methods 1998, 85:107-118

47. Andersen BB, Fabricius K, Gundersen HJ, Jelsing J, Stark AK: No change in neuron numbers in the dentate nucleus of patients with schizophrenia estimated with a new stereological method: the smooth fractionator. J Anat 2004, 205:313-321

48. Soriano FG, Liaudet L, Szabo E, Virag L, Mabley JG, Pacher P, Szabo C: Resistance to acute septic peritonitis in poly(ADP-ribose) polymerase-1-deficient mice. Shock 2002, 17:286-292

49. Shall S, de Murcia G: Poly(ADP-ribose) polymerase-1: what have we learned from the deficient mouse model? Mutat Res 2000, 460:1-15

50. Arteel GE, Thurman RG, Yates JM, Raleigh JA: Evidence that hypoxia markers detect oxygen gradients in liver: pimonidazole and retrograde perfusion of rat liver. $\mathrm{Br} \mathrm{J}$ Cancer 1995, 72:889-895

51. Olsson R, Carlsson PO: Oxygenation of cultured pancreatic islets Adv Exp Med Biol 2006, 578:263-268

52. Raleigh JA, Calkins-Adams DP, Rinker LH, Ballenger CA, Weissler MC, Fowler WC Jr, Novotny DB, Varia MA: Hypoxia and vascular endothelial growth factor expression in human squamous cell carcinomas using pimonidazole as a hypoxia marker. Cancer Res 1998 , 58:3765-3768

53. Schelshorn DW, Schneider A, Kuschinsky W, Weber D, Kruger C, Dittgen T, Burgers HF, Sabouri F, Gassler N, Bach A, Maurer MH: Expression of hemoglobin in rodent neurons. J Cereb Blood Flow Metab 2009, 29:585-595

54. Hunt NH, Grau GE: Cytokines: accelerators and brakes in the pathogenesis of cerebral malaria. Trends Immunol 2003, 24:491-499

55. Lackner P, Beer R, Heussler V, Goebel G, Rudzki D, Helbok R, Tannich E, Schmutzhard E: Behavioural and histopathological alterations in mice with cerebral malaria. Neuropathol Appl Neurobiol 2006, 32:177-188

56. Clavier N, Rahimy C, Falanga P, Ayivi B, Payen D: No evidence for cerebral hypoperfusion during cerebral malaria. Crit Care Med 1999, 27:628-632

57. Nickerson JP, Tong KA, Raghavan R: Imaging cerebral malaria with a susceptibility-weighted MR sequence. Am J Neuroradiol 2009, 30:e85-e86

58. Scheufler KM, Rohrborn HJ, Zentner J: Does tissue oxygen-tension reliably reflect cerebral oxygen delivery and consumption? Anesth Analg 2002, 95:1042-1048

59. Antonova OA, Loktionova SA, Golubeva NV, Romanov YA, Mazurov AV: Damage and activation of endothelial cells during in vitro hypoxia. Bull Exp Biol Med 2007, 144:504-506

60. Yeo TW, Lampah DA, Gitawati R, Tjitra E, Kenangalem E, Piera K, Price RN, Duffull SB, Celermajer DS, Anstey NM: Angiopoietin-2 is associated with decreased endothelial nitric oxide and poor clinical outcome in severe falciparum malaria. Proc Natl Acad Sci USA 2008 , 105:17097-17102

61. Yeo TW, Lampah DA, Gitawati R, Tjitra E, Kenangalem E, McNeil YR, Darcy CJ, Granger DL, Weinberg JB, Lopansri BK, Price RN, Duffull SB, Celermajer DS, Anstey NM: Recovery of endothelial function in severe falciparum malaria: relationship with improvement in plasma L-arginine and blood lactate concentrations. J Infect Dis 2008, 198: 602-608

62. Penet MF, Kober F, Confort-Gouny S, Le FY, Dalmasso C, Coltel N, Liprandi A, Gulian JM, Grau GE, Cozzone PJ, Viola A: Magnetic resonance spectroscopy reveals an impaired brain metabolic profile in mice resistant to cerebral malaria infected with Plasmodium berghei ANKA. J Biol Chem 2007, 282:14505-14514 
63. Blomstrand C: Effect of hypoxia on protein metabolism in neuron- and neuroglia cell-enriched fractions from rabbit brain. Exp Neurol 1970 29:175-188

64. Gjedde A, Marrett S, Vafaee M: Oxidative and nonoxidative metabolism of excited neurons and astrocytes. J Cereb Blood Flow Metab 2002, 22:1-14

65. Franke-Fayard B, Fonager J, Braks A, Khan SM, Janse CJ: Sequestration and tissue accumulation of human malaria parasites: can we learn anything from rodent models of malaria? PLoS Pathog 2010, 6:pii: e1001032

66. Schmidt W, Correa R, Boning D, Ehrich JH, Kruger C: Oxygen transport properties in malaria-infected rodents: a comparison between infected and noninfected erythrocytes. Blood 1994, 83:3746-3752

67. McLaren AT, Marsden PA, Mazer CD, Baker AJ, Stewart DJ, Tsui AK, Li X, Yucel Y, Robb M, Boyd SR, Liu E, Yu J, Hare GM: Increased expression of HIF-1alpha, nNOS, and VEGF in the cerebral cortex of anemic rats. Am J Physiol Regul Integr Comp Physiol 2007, 292 R403-R414

68. Hellwig-Burgel T, Rutkowski K, Metzen E, Fandrey J, Jelkmann W: Interleukin-1beta and tumor necrosis factor-alpha stimulate DNA binding of hypoxia-inducible factor-1. Blood 1999, 94:1561-1567

69. Tuttle SW, Maity A, Oprysko PR, Kachur AV, Ayene IS, Biaglow JE, Koch CJ: Detection of reactive oxygen species via endogenous oxidative pentose phosphate cycle activity in response to oxygen concentration: implications for the mechanism of HIF-1alpha stabilization under moderate hypoxia. J Biol Chem 2007, 282:36790-36796

70. Liu R, Suzuki A, Guo Z, Mizuno Y, Urabe T: Intrinsic and extrinsic erythropoietin enhances neuroprotection against ischemia and reperfusion injury in vitro. J Neurochem 2006, 96:1101-1110

71. Zhang D, Li J, Costa M, Gao J, Huang C: JNK1 mediates degradation HIF-1alpha by a VHL-independent mechanism that involves the chaperones Hsp90/Hsp70. Cancer Res 2010, 70:813-823

72. Anand SS, Babu PP: C-Jun N terminal kinases (JNK) are activated in the brain during the pathology of experimental cerebral malaria Neurosci Lett 2011, 488:118-122

73. Hagen T, Taylor CT, Lam F, Moncada S: Redistribution of intracellular oxygen in hypoxia by nitric oxide: effect on HIF1alpha. Science 2003, 302:1975-1978

74. Medana IM, Day NP, Roberts R, Sachanonta N, Turley H, Pongponratn $\mathrm{E}$, Hien TT, White NJ, Turner GD: Induction of the vascular endothelial growth factor pathway in the brain of adults with fatal falciparum malaria is a non-specific response to severe disease. Histopathology 2010, 57:282-294

75. Uchida T, Rossignol F, Matthay MA, Mounier R, Couette S, Clottes E, Clerici C: Prolonged hypoxia differentially regulates hypoxia-inducible factor (HIF)-1alpha and HIF-2alpha expression in lung epithelial cells: implication of natural antisense HIF-1alpha. J Biol Chem 2004, 279:14871-14878

76. Casals-Pascual C, Idro R, Picot S, Roberts DJ, Newton CR: Can erythropoietin be used to prevent brain damage in cerebral malaria? Trends Parasitol 2009, 25:30-36

77. Prass K, Scharff A, Ruscher K, Lowl D, Muselmann C, Victorov I, Kapinya K, Dirnagl U, Meisel A: Hypoxia-induced stroke tolerance in the mouse is mediated by erythropoietin. Stroke 2003, 34:1981-1986
78. Medana IM, Day NP, Hien TT, White NJ, Turner GD: Erythropoietin and its receptors in the brainstem of adults with fatal falciparum malaria. Malar J 2009, 8:261

79. Casals-Pascual C, Idro R, Gicheru N, Gwer S, Kitsao B, Gitau E, Mwakesi R, Roberts DJ, Newton CR: High levels of erythropoietin are associated with protection against neurological sequelae in African children with cerebral malaria. Proc Natl Acad Sci USA 2008, 105 2634-2639

80. Chong ZZ, Kang JQ, Maiese K: Erythropoietin is a novel vascular protectant through activation of Akt1 and mitochondrial modulation of cysteine proteases. Circulation 2002, 106:2973-2979

81. Li Y, Lu ZY, Ogle M, Wei L: Erythropoietin prevents blood brain barrier damage induced by focal cerebral ischemia in mice. Neurochem Res 2007, 32:2132-2141

82. Beleslin-Cokic BB, Cokic VP, Yu X, Weksler BB, Schechter AN, Noguchi CT: Erythropoietin and hypoxia stimulate erythropoietin receptor and nitric oxide production by endothelial cells. Blood 2004, 104:2073-2080

83. Contaldo C, Elsherbiny A, Lindenblatt N, Plock JA, Trentz O, Giovanoli $P$, Menger MD, Wanner GA: Erythropoietin enhances oxygenation in critically perfused tissue through modulation of nitric oxide synthase. Shock 2009, 31:599-606

84. Gramaglia I, Sobolewski P, Meays D, Contreras R, Nolan JP, Frangos JA, Intaglietta M, Van Der Heyde HC: Low nitric oxide bioavailability contributes to the genesis of experimental cerebral malaria. Nat Med 2006, 12:1417-1422

85. Yeo TW, Lampah DA, Gitawati R, Tjitra E, Kenangalem E, McNeil YR, Darcy CJ, Granger DL, Weinberg JB, Lopansri BK, Price RN, Duffull SB, Celermajer DS, Anstey NM: Impaired nitric oxide bioavailability and L-arginine reversible endothelial dysfunction in adults with falciparum malaria. J Exp Med 2007, 204:2693-2704

86. Hansen TD, Warner DS, Todd MM, Vust LJ: The role of cerebral metabolism in determining the local cerebral blood flow effects of volatile anesthetics: evidence for persistent flow-metabolism coupling. J Cereb Blood Flow Metab 1989, 9:323-328

87. Hou H, Grinberg OY, Taie S, Leichtweis S, Miyake M, Grinberg S, Xie $H$, Csete M, Swartz HM: Electron paramagnetic resonance assessment of brain tissue oxygen tension in anesthetized rats. Anesth Analg 2003, 96:1467-1472

88. Hoffman WE, Wheeler P, Edelman G, Charbel FT, Torres NJ, Ausman JI: Hypoxic brain tissue following subarachnoid hemorrhage. Anesthesiology 2000, 92:442-446

89. Hoffman WE, Edelman G: Enhancement of brain tissue oxygenation during high dose isoflurane anesthesia in the dog. J Neurosurg Anesthesiol 2000, 12:95-98

90. Li QF, Zhu YS, Jiang H: Isoflurane preconditioning activates HIF1alpha, iNOS and Erk1/2 and protects against oxygen-glucose deprivation neuronal injury. Brain Res 2008, 1245:26-35

91. Wang C, Weihrauch D, Schwabe DA, Bienengraeber M, Warltier DC, Kersten Jr, Pratt PF Jr, Pagel PS: Extracellular signal-regulated kinases trigger isoflurane preconditioning concomitant with upregulation of hypoxia-inducible factor-1alpha and vascular endothelial growth factor expression in rats. Anesth Analg 2006, 103: 281-288 